\title{
Maps of the Arctic Alaska Boundary Area as Defined by the U.S. Arctic Research and Policy Act-Including Geospatial Characteristics of Select Marine and Terrestrial Features
}

By Dee M. Williams and Christopher L. Richmond

Pamphlet to accompany

Scientific Investigations Map 3484

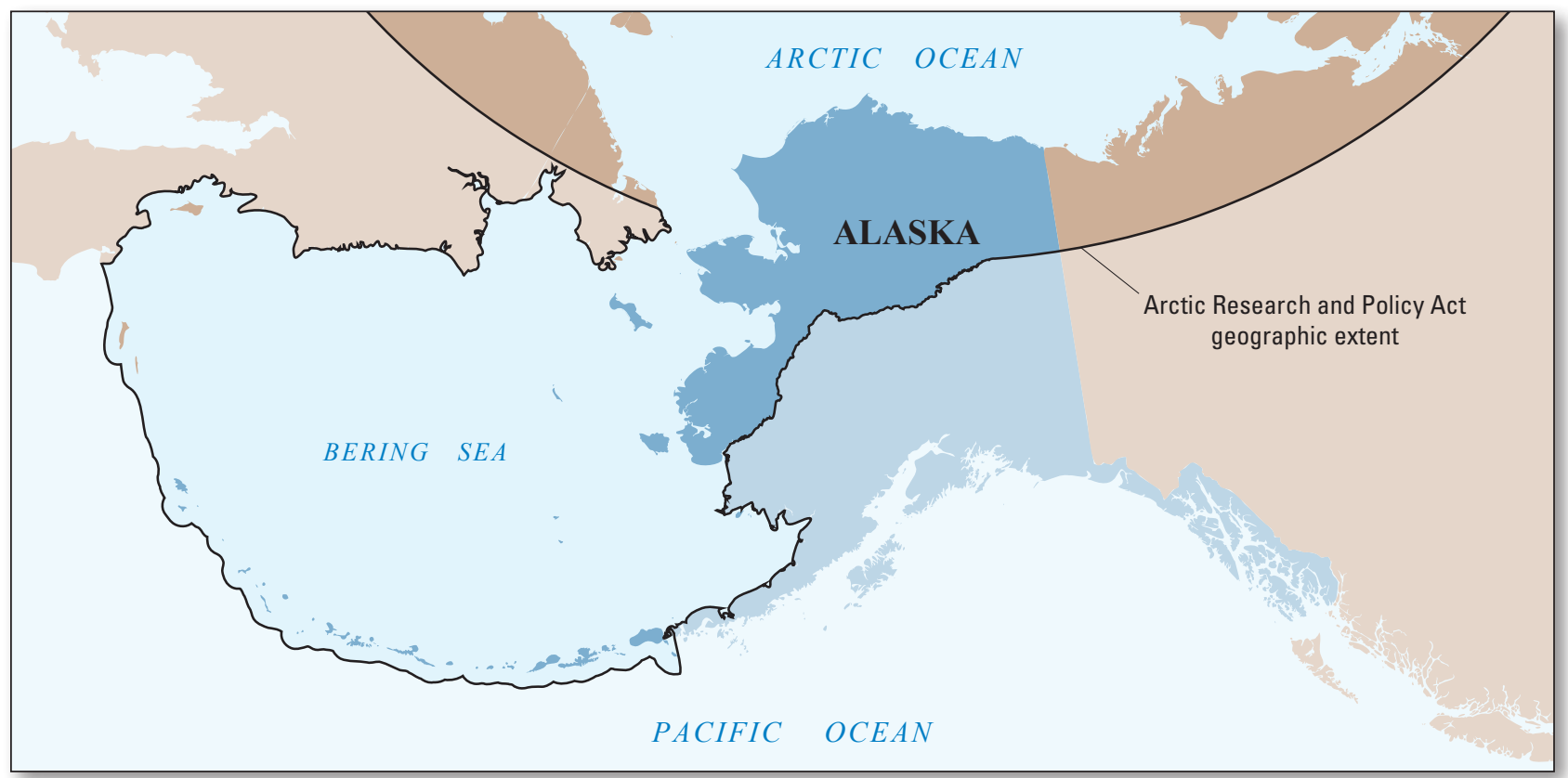

U.S. Department of the Interior

U.S. Geological Survey 


\section{U.S. Geological Survey, Reston, Virginia: 2021}

For more information on the USGS — the Federal source for science about the Earth, its natural and living resources, natural hazards, and the environment—visit https://www.usgs.gov or call 1-888-ASK-USGS (1-888-275-8747).

For an overview of USGS information products, including maps, imagery, and publications, visit https://store.usgs.gov.

Any use of trade, firm, or product names is for descriptive purposes only and does not imply endorsement by the U.S. Government.

Although this information product, for the most part, is in the public domain, it also may contain copyrighted materials as noted in the text. Permission to reproduce copyrighted items must be secured from the copyright owner.

Suggested citation:

Williams, D.M., and Richmond, C.L., 2021, Maps of the Arctic Alaska boundary area as defined by the U.S. Arctic Research and Policy Act—Including geospatial characteristics of select marine and terrestrial features: U.S. Geological Survey Scientific Investigations Map 3484, 5 sheets, pamphlet 7 p., https://doi.org/10.3133/sim3484.

ISSN 2329-132X (online)

Cover. Schematic showing the Arctic Research and Policy Act geographic extent through Alaska. 


\section{Acknowledgments}

The authors would like to thank U.S. Geological Survey (USGS) colleagues Tracy Fuller, Ingrid Verstraeten, and John Osias for helpful internal reviews and editorial suggestions that improved the report. We also thank the following external reviewers from sister Federal agencies for comments that substantially influenced and improved the development of map products: John Farrell (U.S. Arctic Research Commission), Alyson Azarra (U.S. Department of Transportation), Amanda Williams (U.S. Department of State), and Toby Megraw (National Geospatial Intelligence Agency). Furthermore, USGS employees Phil Rufe, William Marken, Jacqueline Olson, and Joseph Mangano provided helpful graphics editing that also improved the map products after C.L. Richmond completed the GIS and cartography. Finally, we thank John Buursma (USGS) for help moving this report through the production process in a timely manner.

\section{Contents}

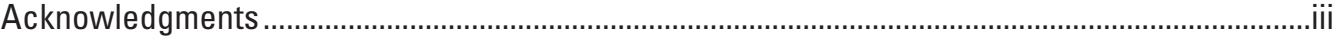

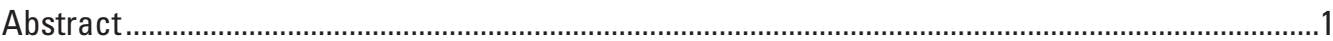

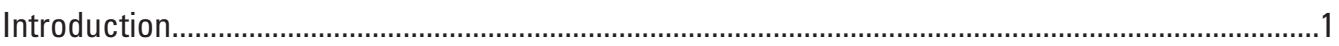

Description of Map Sheet Contents .............................................................................................

Map Sheet 1—Arctic Research and Policy Act Boundary Map—Bering Sea ............................4

Map Sheet 2-Arctic Research and Policy Act Boundary Map-Circumpolar Perspective .....4

Map Sheet 3-Arctic Research and Policy Act Boundary Map-U.S. Territorial Limits.............5

Map Sheet 4-Arctic Research and Policy Act Boundary Map—Mainland Alaska ...................6

Map Sheet 5-Arctic Research and Policy Act Boundary Map—Aleutian Islands....................6

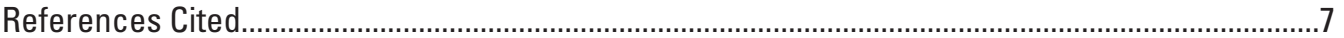

\section{Figures}

1. Map showing regional geography of the Arctic Research and Policy Act boundary, 10-degree-Celsius isotherm, International Maritime Boundary, U.S. Exclusive Economic Zone, and 12- and 24-mile Maritime Limits

\section{Map Sheets}

[Note: Map sheets are available at https://doi.org/10.3133/sim3484]

1. Arctic Research and Policy Act Boundary Map-Bering Sea

2. Arctic Research and Policy Act Boundary Map-Circumpolar Perspective

3. Arctic Research and Policy Act Boundary Map-U.S. Territorial Limits

4. Arctic Research and Policy Act Boundary Map—Mainland Alaska

5. Arctic Research and Policy Act Boundary Map—Aleutian Islands 


\section{Conversion Factors}

U.S. customary units to International System of Units

\begin{tabular}{|c|c|c|}
\hline Multiply & By & To obtain \\
\hline \multicolumn{3}{|c|}{ Length } \\
\hline inch (in.) & 2.54 & centimeter $(\mathrm{cm})$ \\
\hline inch (in.) & 25.4 & millimeter (mm) \\
\hline mile (mi) & 1.609 & kilometer (km) \\
\hline mile, nautical (nmi) & 1.852 & kilometer (km) \\
\hline
\end{tabular}

International System of Units to U.S. customary units

\begin{tabular}{lll}
\hline \multicolumn{1}{c}{ Multiply } & \multicolumn{1}{c}{ By } & \multicolumn{1}{c}{ To obtain } \\
\hline & Length & \\
$\operatorname{meter}(\mathrm{m})$ & 3.281 & foot $(\mathrm{ft})$ \\
$\operatorname{meter}(\mathrm{m})$ & 1.094 & yard (yd) \\
kilometer $(\mathrm{km})$ & 0.6214 & mile (mi) \\
kilometer $(\mathrm{km})$ & 0.5400 & mile, nautical (nmi) \\
\hline
\end{tabular}

Temperature in degrees Celsius $\left({ }^{\circ} \mathrm{C}\right)$ may be converted to degrees Fahrenheit $\left({ }^{\circ} \mathrm{F}\right)$ as follows:

$$
{ }^{\circ} \mathrm{F}=\left(1.8 \times{ }^{\circ} \mathrm{C}\right)+32 .
$$

Temperature in degrees Fahrenheit $\left({ }^{\circ} \mathrm{F}\right)$ may be converted to degrees Celsius $\left({ }^{\circ} \mathrm{C}\right)$ as follows:

$$
{ }^{\circ} \mathrm{C}=\left({ }^{\circ} \mathrm{F}-32\right) / 1.8 \text {. }
$$

\section{Datum}

Horizontal coordinate information is referenced to the World Geodetic System 1984 (WGS 84). 


\title{
Abbreviations
}

\author{
AMI Alaska Mapping Initiative \\ ARPA U.S. Arctic Research and Policy Act \\ DK Denmark (abbreviation on some map sheets) \\ ECS extended continental shelf \\ FI Finland (abbreviation on some map sheets) \\ IE Ireland (abbreviation on some map sheets) \\ ifSAR interferometric synthetic aperture radar \\ IS Iceland (abbreviation on some map sheets) \\ NO Norway (abbreviation on some map sheets) \\ NOAA National Oceanic and Atmospheric Administration \\ NSIDC National Snow and Ice Data Center \\ PAD-US Protected Area Database of the United States \\ SE Sweden (abbreviation on some map sheets) \\ SJ Svalbard and Jan Mayen (abbreviation on some map sheets) \\ UK United Kingdom (abbreviation on some map sheets) \\ US United States of America (abbreviation on some map sheets) \\ USGS U.S. Geological Survey
}




\title{
Maps of the Arctic Alaska Boundary Area as Defined by the U.S. Arctic Research and Policy Act—Including Geospatial Characteristics of Select Marine and Terrestrial Features
}

\author{
By Dee M. Williams and Christopher L. Richmond
}

\section{Abstract}

This pamphlet presents a series of general reference maps showing relevant geospatial features of the U.S. Arctic boundary as defined by the U.S. Congress since 1984. The first generation of the U.S. Arctic Research and Policy Act (ARPA) boundary maps was originally formatted and published in 2009 by a private firm contracted with the National Science Foundation and the U.S. Arctic Research Commission. Recognizing the steadily increasing relevance of Arctic issues to national and global affairs that requires more functional projections and online tools, the U.S. Geological Survey (USGS) Alaska Regional Office and the National Geospatial Technical Operations Center developed this updated series of ARPA boundary maps. Map sheet 1 shows the ARPA boundary as it relates to Alaska and marine features of the Bering Sea. Map sheet 2 shows the ARPA boundary from a circumpolar perspective. Map sheet 3 shows the national boundary of the U.S. 200-nautical-mile Exclusive Economic Zone through the Bering, Chukchi, and Beaufort Seas, facilitating Arctic domain awareness and more consistent territorial assessments of the U.S. Arctic. Map sheet 4 shows, in poster-size detail, the ARPA boundary as it relates to terrestrial features of Arctic Alaska north of the Yukon and Kuskokwim Rivers. Map sheet 5 shows, in poster-size detail, the ARPA boundary as it relates to marine and terrestrial features of the Aleutian Islands. These new maps collectively illustrate several value-added attributes, including updated bathymetry and shoreline refinements, demographic information, international borders and offshore territorial claims, Alaska conservation areas, Alaska land cover, Alaska terrestrial shaded relief, annual sea ice maximum extent, annual circumpolar 10-degree-Celsius isotherm, location of active volcanoes, and updated geospatial information. The static PDF-file maps offer value as standalone products but are intended for use with the Arctic Alaska Mapper interactive website that can be sourced by annual data updates, allowing users to access the various map layers in a dynamic up-to-date environment.

\section{Introduction}

Multiple competing definitions of the Arctic are in common use, yielding differing descriptions of the land and sea areas encompassed by the term (for example, see Rekacewicz, 2005). In this report, the U.S. Geological Survey (USGS) presents a series of general reference maps and underlying datasets that provide updated geospatial information about the Arctic boundary as defined by the U.S. Arctic Research and Policy Act (ARPA) of 1984. The Act (Title I of Public Law 98-373, as amended in 1990 by Public Law 101-609), (1) establishes the institutional framework for a comprehensive policy to set national research needs and objectives in the Arctic and (2) defines the relevant boundary line for U.S. operational and science-administration purposes. Section 112 of the Act declares the following: "As used in this Title, the term Arctic means all United States and foreign territory north of the Arctic Circle and all United States territory north and west of the boundary formed by the Porcupine, Yukon, and Kuskokwim Rivers [in Alaska]; all contiguous seas, including the Arctic Ocean and the Beaufort, Bering, and Chukchi Seas; and the Aleutian chain." This definition, which is codified at 15 U.S.C. 4111, notably includes certain parts of Alaska below the Arctic Circle, including the Aleutian Islands and parts of central and western mainland Alaska, such as the Seward Peninsula and the Yukon Delta.

By contrast, the most universal definition of the Arctic defines the region as the land and sea area north of the Arctic Circle (a circle of approximate lat $66^{\circ} 30^{\prime} \mathrm{N}$.). Within this zone, the sun remains generally above the horizon for 24 continuous hours at least once per year (at summer solstice) and below the horizon for 24 continuous hours at least once per year (at winter solstice). Other scientifically derived definitions of the Arctic are based on single variable measures such as average temperature, extent of the northern tree line, extent of permafrost on land, extent of sea ice on the ocean, or the area encompassed in the northern hemisphere by an isotherm line where the average temperature for the warmest month (July) is less than 10 degrees 
Celsius $\left({ }^{\circ} \mathrm{C}\right)\left(50\right.$ degrees Fahrenheit $\left.\left[{ }^{\circ} \mathrm{F}\right]\right)$. This last definition results in an irregularly shaped Arctic region that annually excludes some land and sea areas north of the Arctic Circle, but also typically includes sizable land and sea areas south of the Arctic Circle, such as most of the Bering Sea and the Aleutian Islands (Congressional Research Service, 2021). The $10^{\circ} \mathrm{C}$ isotherm typically represents a contour fully encompassing the Bering Sea and appearing loosely compatible with the ARPA boundary (see map sheet 2). In a similar manner, this map series also deliberately enables a convenient comparison between the static ARPA boundary and other fluctuating variables such as extent of sea ice on Arctic oceans (see map sheets 2 and 4) and extent of the northern tree line in Alaska (northern edge of green "Forest and woodland" areas classified in map sheet 4).

Given the various Arctic boundary definitions, the relatively irregular and imprecise statutory definition of this boundary in ARPA establishes a clear need for visual representation and cartographic detail, even among those readers already well familiar with Alaskan geography. Toward that end, a first generation of ARPA boundary maps (consisting of two plates) was originally formatted in 2009 as a geographic information system (GIS) shapefile with associated metadata by Nuna Technologies, working under contract arrangements with the National Science Foundation and the U.S. Arctic Research Commission. That shapefile shows a generalized coast of Alaska based on 1:63,360 scale digital data and features a bright red line to mark the boundary area topology from an international perspective relative to the Bering Sea (map sheet 1) and to the circumpolar Arctic Circle (map sheet 2). Both maps, as well as the GIS shapefile with associated metadata, can be accessed at the U.S. Arctic Research Commission website, https://www.arctic. gov/maps/.

Many factors have contributed to a growing administrative and scientific interest in updating and expanding the geospatial information in the initial singularly focused and static ARPA boundary maps. The most fundamental rationale for developing an updated map series is the increasing relevance of Arctic issues to national and global affairs that requires more precise and functional projections with refined geospatial information. Over the past 4 decades, the Arctic environment has undergone substantial physical changes as air temperatures increase, sea and land ice diminish, terrestrial snow cover declines, permafrost thaws, and shorelines move with predominant erosional retreat (Gibbs and Richmond, 2017; Overland and others, 2019). Although warming and cooling cycles have occurred over millennia, the current warming trend is unprecedented in recorded history and affects the region at a much faster rate than other places on Earth (Thoman and others, 2020; Arctic Monitoring and Assessment Programme, 2021). These ongoing physical changes have potential implications in the Arctic and beyond for altering weather patterns and storm events, restructuring marine and terrestrial ecosystems, expanding marine transport, accessing mineral and biological resources, threatening human health and well-being, and disrupting national security (for example, Taylor and others, 2017; Overland and others, 2019; Richter-Menge and others, 2019).

In the context of such broad transition, the United States and other Arctic and non-Arctic nations with substantial polar interests recognize the need to strengthen research coordination efforts and to develop a wide array of better tools (including geospatial reference maps) to monitor, understand, and forecast the scope of changes underway in the Arctic (Congressional Research Service, 2021). This USGS series of new ARPA boundary maps is intended to facilitate opportunities for enhanced situational awareness and research coordination, especially among domestic partners and stakeholders focused on Arctic Alaska.

Moreover, the rationale for developing updated and more detailed ARPA boundary maps also fulfills more specific topical interests and needs. A perceived need exists in many quarters to include more detail about terrestrial features of Arctic Alaska to assist in resolving common misunderstandings about the basic geography, scope, and scale of Arctic matters. A new generation of geospatial tools could help to standardize the way U.S. Government agencies represent the Arctic and calculate the various resources in it. For example, despite the growing U.S. national interest in Arctic affairs, fundamental questions stemming from imprecise geospatial information that are not always readily or consistently answered continually arise in the American research community. Such basic questions include the following examples:

- What is the total size of the U.S. Arctic?

- How many square miles of land does the U.S. Arctic encompass?

- How many square miles of ocean are encompassed within the Arctic part of the U.S. Exclusive Economic Zone?

- How significantly does the Arctic Alaska coastal zone change on an annual basis?

- How does our static political definition of the Arctic compare with alternative scientific definitions based on fluctuating annual data?

- What substantive social changes are underway in Arctic demography, land conservation, marine shipping, and territorial claims that warrant geospatial updates?

Moving forward, the U.S. could benefit from a uniform geospatial reference framework and easily accessed viewing platform to address such routine questions in a more consistent manner.

Thus, this new map series (and the Arctic Alaska Mapper interactive website, https:/www.usgs.gov/tools/arctic-alaskamapper) can provide useful tools toward these specific various goals. They can facilitate opportunities for enhanced situational awareness and research coordination in the Arctic region but should not be considered authoritative for other detail-oriented purposes, such as navigation. In the collaborative spirit of the Arctic Research and Policy Act (ARPA), users of these geospatial reference tools are afforded access to synthesized information sourced from various institutions and scientific disciplines involved in managing and researching Arctic Alaska boundary-area resources. This series of revised maps (and the Arctic Alaska Mapper interactive website, https://www.usgs.gov/tools/arctic-alaska-mapper) with updated source files and associated metadata provide a more panoptic assembly of relevant geospatial information that can be customized to fit the needs of many different users. The map products can be used and distributed without limitation or restriction. 
This pamphlet provides a brief descriptive commentary on the major features and data sources of each map sheet as they are introduced. The corresponding map products can then be accessed by hyperlink text embedded in the table of contents. Additionally, figure 1 is provided directly within this pamphlet merely as a convenient point of geographic reference for readers to follow the narrative more easily. Figure 1 consolidates some key features of each map sheet but is not intended to substitute for any of the five new sheets. Figure 1 does, however, deliberately facilitate a panoptic view of alternative popular definitions of the Arctic boundary, including the boundary as variably defined by the Arctic Circle, the ARPA, the extent of ocean sea ice, or the area encompassed by a $10{ }^{\circ} \mathrm{C}$ isotherm line.

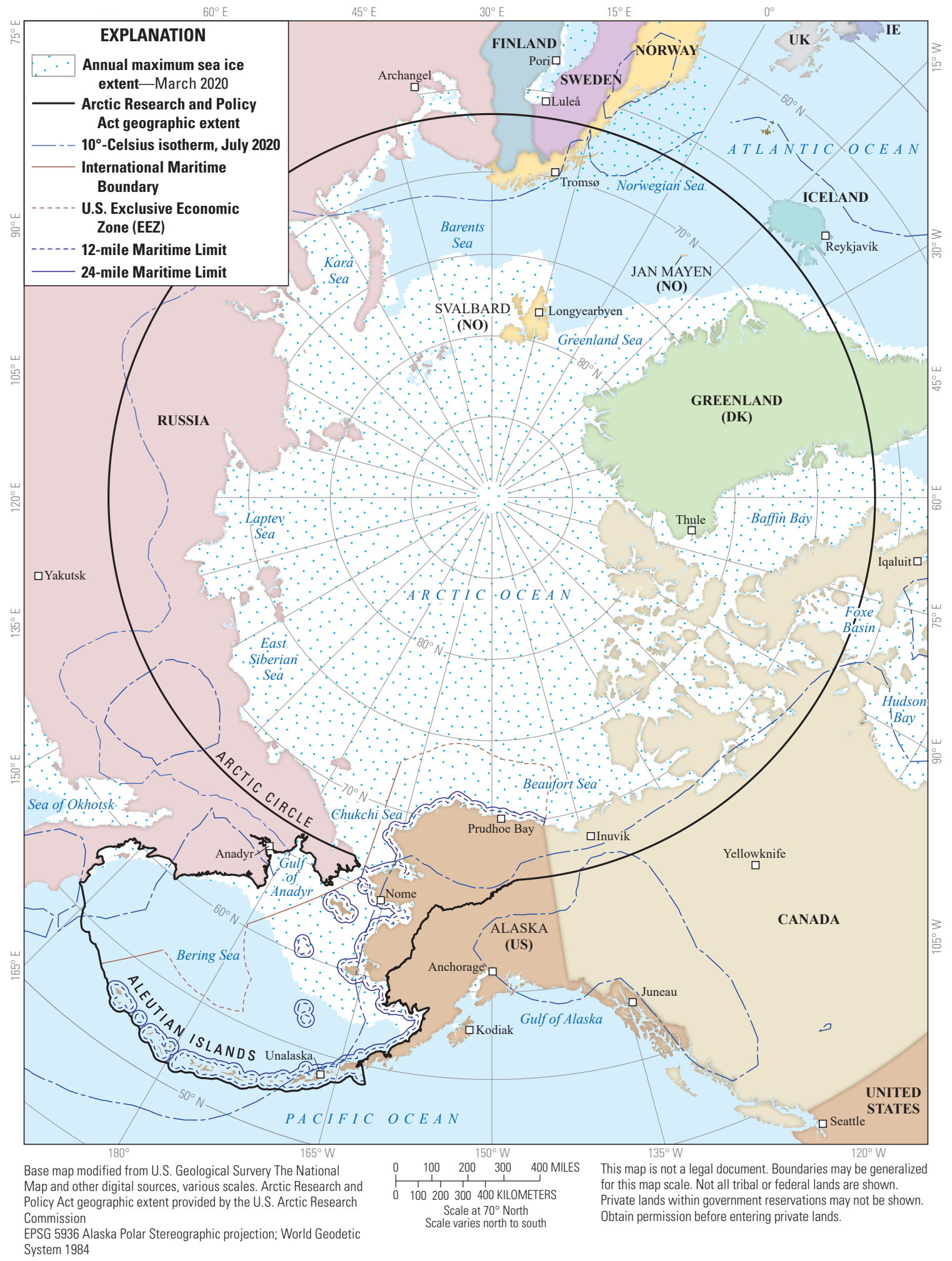

Figure 1. Map showing regional geography of the Arctic Research and Policy Act boundary, 10-degree-Celsius isotherm, International Maritime Boundary, U.S. Exclusive Economic Zone, and 12- and 24-mile Maritime Limits. 


\section{Description of Map Sheet Contents}

\section{Map Sheet 1-Arctic Research and Policy Act Boundary Map-Bering Sea}

This map sheet features the continuous ARPA boundary as it relates specifically to Alaska, the Russian coast, and selected marine features of the Bering Sea. It highlights the ARPA boundary area as it dips south from the Arctic Circle in northwestern Alaska after intersecting with the Porcupine River to follow the course of the Yukon River, then continues along the Kuskokwim River from the small village of Kalskag to the coastline of Kuskokwim Bay in southwestern Alaska. (A 45-kilometer part of the boundary at longitude 160 degrees $\left({ }^{\circ}\right)$ West joins the gap between the Yukon and Kuskokwim Rivers, establishing continuous polygon topology.) The boundary line then follows the shoreline around Bristol Bay to the Alaska Peninsula as far as False Pass before dropping southward below Sanak Island to follow a nonlinear 24-nautical-mile radial buffer south of the Aleutian Islands from Unimak Island (East of Unalaska) westward beyond Attu Island and across the International Date Line to meet the shoreline of Russia near the Kamchatka River. The boundary line then goes northeast along the Russian coast through Chukotka and along the Gulf of Anadyr until it rejoins the Arctic Circle to the north. An inset in the upper left corner of the map shows the Bering Sea part of the ARPA boundary within the full context of the circumpolar Arctic Circle. The original source file and available metadata record for the ARPA boundary shapefile can be accessed through the U.S. Arctic Research Commission website at https://www.arctic.gov/ maps/.

Map sheet 1 shows an Alaska Polar Stereographic projection at an approximate scale of 1 inch (in.) to 200 miles (mi). The map spans approximately from long $129^{\circ} \mathrm{W}$. to $175^{\circ}$ E., and from lat 47 to $75^{\circ} \mathrm{N}$. Relevant sections of additional data layers were selected using the attribute query tool and trace tool in Esri ArcGIS Pro. For example, the Arctic Circle line establishes a permanent substantial reference for global latitudes and longitudes and was sourced from ArcGIS at https:// services.arcgis.com/P3ePLMYs2RVChkJx/arcgis/rest/services/ World_GeoReference_Lines/FeatureServer. Major rivers (such as the Yukon, Porcupine, and Kuskokwim Rivers) were queried and copied from the Major Rivers dataset of the USGS National Map, available at https://prd-tnm.s3.amazonaws.com/index. html?prefix=StagedProducts/. The population of Alaska cities and villages is derived from the 2010 U.S. Census, available at https://live.laborstats.alaska.gov/landing/pop-cen.html. The geographic locations of place names are derived from the USGS National Map (see https://www.usgs.gov/core-science-systems/ national-geospatial-program/national-map).

Map sheet 1 shows shaded relief from recently acquired three-dimensional elevation data for land surfaces in Alaska. In 2011, the Alaska Congressional delegation formally requested Federal support in modernizing Alaska map data. "The USGS National Geospatial Program developed the Alaska Mapping Initiative (AMI) to collaborate with State and other Federal partners in Alaska in acquiring three-dimensional elevation data to improve statewide topographic mapping products. AMI coordinates Federal activities through the Alaska Mapping Executive Committee and State efforts through Alaska's [Geospatial Council] to ensure a unified approach for consistent data acquisition and enhancement of elevation data products" (U.S. Geological Survey, 2021). Collection of a 5-meter (m)-resolution elevation grid for Alaska began in 2010 and was completed in 2020, replacing the former 60-m statewide elevation grid. "AMI attained interferometric synthetic aperture radar (IfSAR) data to generate digital elevation models (DEMs). This radar-mapping technology is an effective tool for collecting data under challenging circumstances such as cloud cover, extreme weather conditions, rugged terrain, and remote locations" (U.S. Geological Survey, 2021). Alaska IfSAR acquisition supports the broader national 3D Elevation Program (https://www.usgs.gov/ core-science-systems/ngp/3dep). The data are free to the public for any use and can be accessed at https://geoportal.dggs.dnr. alaska.gov/portal/home/item.html?id=d7bb272d4dcb4cfd9577f5 e8e50c4ca8.

Additionally, this map sheet represents bathymetric contours of the coastal zone and seafloor derived from the General Bathymetric Chart of the Oceans (GEBCO_2020) grid, which is a global bathymetry compilation largely based on a database of ship-track soundings combined with satellite-derived gravity data. Data from the GEBCO_2020 grid can be accessed at https:// tiles.arcgis.com/tiles/C8EMgrsFcRFL6LrL/arcgis/rest/services/ GEBCO_contours/MapServer. Information concerning the generation of the grid is available at the GEBCO website, https:// www.gebco.net/data_and_products/gridded_bathymetry_data/ gebco_2020/. This representation of bathymetric data should not be used for navigation or for any other purpose relating to safety at sea.

\section{Map Sheet 2-Arctic Research and Policy Act Boundary Map-Circumpolar Perspective}

Map sheet 2 features the full ARPA boundary area from a global circumpolar perspective. It conveys key components of Arctic geospatial information otherwise absent from map sheets 1 and 3, including Arctic Circle intersection with circumpolar international boundaries, an Arctic longitudinal compass, 2020 representation of maximum sea ice extent, and 2020 representation of the July $10^{\circ} \mathrm{C}$ isotherm. Although the staticmap PDF file shows annual ice and isotherm data from 2020 until revised, the Arctic Alaska Mapper interactive website (https:// www.usgs.gov/tools/arctic-alaska-mapper) can be designed to update sea ice extent and isotherm extent as new annual data become available.

Map sheet 2 shows an Alaska Polar Stereographic projection at an approximate scale of $1 \mathrm{in}$. to $550 \mathrm{mi}$. The map spans approximately from lat 50 to $90^{\circ} \mathrm{N}$. Relevant sections of additional data layers were selected using the attribute query tool and trace tool in Esri ArcGIS Pro. The original source file and available metadata record for the ARPA boundary shapefile shown in this map sheet can be accessed through the U.S. Arctic Research Commission website at https://www.arctic.gov/maps/. 
The map sheet shows that eight nations hold territorial claims north of the Arctic Circle, including the United States (via Alaska), Canada, Denmark (via Greenland), Iceland, Norway, Sweden, Finland, and Russia. These eight countries are often referred to as the Arctic States, and they are the member states of the Arctic Council. The Arctic Council was created in 1996 through Ministerial Joint Declaration in Ottawa as an international forum that operates on the basis of consensus, rather than treaty, to emphasize the peaceful and cooperative nature of the Arctic region. In addition to the eight member states, six organizations representing Arctic indigenous peoples have status as Permanent Participants. Additionally, 13 non-Arctic states, 13 intergovernmental organizations, and 12 nongovernmental organizations have been approved as observers, making for a current total of 38 observer states and organizations (Arctic Council, 2021). This growing international tally of highly attentive participants in Arctic affairs further supports the rationale for timely development of this updated map series.

Map sheet 2 shows national boundaries using administrative data from Esri base-map layers for the world (http://www.arcgis. com/home/item.html?id=30e5fe3149c34df1ba922e6f5bbf8 08f). More information about this map layer, including the terms of use, can be accessed at https://services.arcgisonline.com/ arcgis/rest/services/Reference/World_Boundaries_and_Places/ MapServer. The boundaries shown in this dataset are for visual purposes only and do not represent legal delineations.

Map sheet 2 shows maximum sea ice extent for the latest year on record (2020). "Since the late 1970s, satellites have been used to monitor the extent and concentration of sea ice around the world. Areas of the ocean that have frozen are considered 'sea ice,' and can vary from slushy, barely solid areas to sheets of ice that are several meters thick" (Esri, 2021a). Each day, the National Snow and Ice Data Center (NSIDC) generates sea ice extent analyses from various microwave satellite data sources (https://nsidc.org/arcticseaicenews/category/daily-image/). A smoothing algorithm is applied to the original shapefiles accessed from NSIDC. The Arctic sea ice maximum marks the day of the year when Arctic sea ice reaches its largest extent. The sea ice maximum occurs at the end of the winter cold season, which usually begins in September and ends in March. The NSIDC data source is updated annually and can be accessed at https:// services9.arcgis.com/RHVPKKiFTONKtxq3/arcgis/rest/services/ seaice_extent_N_v1/FeatureServer.

This map sheet also shows the $10^{\circ} \mathrm{C}$ isotherm as measured in July for the latest year on record (2020). An "isotherm" is a line on a weather map showing equal or constant temperature. In some scientific circles, the Arctic is defined as the area where the average temperature for the warmest month (July) is less than $10^{\circ} \mathrm{C}\left(50^{\circ} \mathrm{F}\right)$. This irregular and shifting July isotherm closely corresponds to the northern limit of tree growth, which varies above and below the Arctic Circle. This data source is updated annually to the Arctic Alaska Mapper interactive website (https:/www.usgs.gov/tools/arctic-alaska-mapper) and can be accessed at https://psl.noaa.gov/data/gridded/data.ncep.reanalysis. surface.html.

\section{Map Sheet 3-Arctic Research and Policy Act Boundary Map-U.S. Territorial Limits}

Map sheet 3 replicates the ARPA Bering Sea boundary area from map sheet 1 , but within that international context it explicitly delineates the full extent of Arctic territorial land and waters claimed by the United States. Because the ARPA boundary was established by Congress to define the Arctic for U.S. operational and science administration purposes, this map series includes a sheet that explicitly delineates the extent of U.S. Arctic territorial claims and maritime limits, including territorial seas (out to 12 nautical miles [nmi]), the contiguous zone (out to $24 \mathrm{nmi}$ ), and the U.S. Exclusive Economic Zone (out to $200 \mathrm{nmi}$ ), plus maritime boundaries with adjacent or opposite countries.

The map sheet shows an Alaska Polar Stereographic projection at an approximate scale of $1 \mathrm{in}$. to $193 \mathrm{mi}$. The map spans approximately from long 129 to $175^{\circ} \mathrm{W}$., and from lat 47 to $75^{\circ} \mathrm{N}$. Relevant sections of additional data layers were selected using the attribute query tool and trace tool in Esri ArcGIS Pro. The original source file and available metadata record for the ARPA boundary shapefile shown in this map sheet can also be accessed through the U.S. Arctic Research Commission website at https://www.arctic.gov/maps/.

The U.S. Exclusive Economic Zone was established in March 1983 under President Ronald Reagan by Presidential Proclamation No. 5030. The United States has additional interests to claim extended continental shelf (ECS) jurisdiction in several offshore areas, including in the Bering Sea and the Arctic Ocean north of Alaska. "The work to delineate the U.S. extended continental shelf is ongoing and coordinated by the ECS Task Force, an interagency body of the U.S. Government. The ECS Task Force is responsible for coordinating the collection and analysis of all relevant data and preparing the necessary documentation to establish the outer limits of the U.S. ECS in accordance with international law" (U.S. Department of State, 2021). Once established, those data can be added to the Arctic Alaska Mapper interactive website (https://www.usgs.gov/tools/ arctic-alaska-mapper) intended to accompany this map series.

The map sheet shows the maritime limits and boundaries of the United States as depicted by the National Oceanic and Atmospheric Administration (NOAA), National Ocean Service, Office of Coast Survey. "Maritime limits for the United States are measured from the U.S. baseline, recognized as the lowwater line along the coast as marked on NOAA nautical charts in [accordance with the articles of the Law of the Sea]. The baseline and related maritime limits are reviewed and approved by the interagency U.S. Baseline Committee" (Esri, 2021b). The primary purpose of this dataset is to update the official depiction of these maritime limits and boundaries on NOAA nautical charts. The Office of Coast Survey shows on its nautical charts the territorial sea (out to $12 \mathrm{nmi}$ ), contiguous zone ( 24 out to nmi), and U.S. Exclusive Economic Zone (out to $200 \mathrm{nmi}$ ), plus maritime boundaries with adjacent or opposite countries. U.S. maritime limits shift over time and undergo revision depending upon aggregated accretion or erosion of the charted low water line. The U.S. maritime limits and boundaries data source can be accessed at http://www.nauticalcharts.noaa.gov/csdl/mbound.htm. 


\section{Map Sheet 4-Arctic Research and Policy Act Boundary Map-Mainland Alaska}

Map sheet 4 shows, in poster-size detail, the ARPA boundary area as it relates to terrestrial features of mainland Arctic Alaska north and west of the Yukon and Kuskokwim Rivers. The map sheet conveys key components of Arctic geospatial information otherwise absent from map sheets 1-3, including more detailed city/village locations and relative population sizes, land-cover classification, tree-line extent (shown as the northern edge of green "Forest and woodland" areas) juxtaposed with the ARPA boundary and the Arctic Circle, delineation of conservation areas (National Parks and Preserves, and National Wildlife Refuges), delineation of National Petroleum Reserve-Alaska, and updated geospatial information. The lower right corner contains an inset of the full ARPA boundary through the circumpolar Arctic that shows the locations and relative population size of major Arctic cities and the maritime limits of Arctic nation Exclusive Economic Zones.

The map sheet shows an Alaska Polar Stereographic projection at an approximate scale of $1 \mathrm{in}$. to $37 \mathrm{mi}$. The map spans approximately from long 141 to $178^{\circ} \mathrm{W}$., and from lat 59 to $71^{\circ} \mathrm{N}$. Relevant sections of additional data layers were selected using the attribute query tool and trace tool in Esri ArcGIS Pro. An inset in the upper left corner of the map shows the terrestrial part of the ARPA boundary in the full context of Alaskan geography. The original source file and available metadata record for the ARPA boundary shapefile shown in this map sheet can also be accessed through the U.S. Arctic Research Commission website at https://www.arctic.gov/maps/.

Map sheet 4 shows vegetation land cover derived from the GAP/LANDFIRE National Terrestrial Ecosystems database, based on the NatureServe Ecological Systems Classification (U.S. Geological Survey, 2016). This dataset provides the foundation of one of the most detailed, consistent maps of vegetation available for the United States. These data facilitate the planning and management for biological diversity on a regional and national scale and can be accessed at https://www.usgs.gov/corescience-systems/science-analytics-and-synthesis/gap/science/ land-cover-data-overview.

This map sheet shows boundary lines of various conservation areas managed by bureaus of the Department of the Interior: the National Park Service, the Fish and Wildlife Service, and the Bureau of Land Management. The Protected Areas Database of the United States (PAD-US) is administered by the USGS and consists of the Nation's official inventory of public open space and private protected areas (https://www.usgs. gov/core-science-systems/science-analytics-and-synthesis/gap/ science/protected-areas). These PAD-US 2.1 data can be accessed at https://maps.usgs.gov/padus/.

Map sheet 4 shows Arctic maritime boundaries from a dataset that combined the marine boundaries and the Exclusive Economic Zone polygon lines that indicate the region claimed by different countries. The source data can be accessed at https:/hub.arcgis.com/datasets/nga::arctic-maritime-boundaries.
This map sheet shows an Arctic Ocean base map that features marine bathymetry designed and developed by Esri and its licensors. More information on this base-map layer can be accessed at http:/goto.arcgisonline.com/maps/ Arctic_Ocean_Base.

\section{Map Sheet 5-Arctic Research and Policy Act Boundary Map-Aleutian Islands}

Map sheet 5 shows, in poster-size detail, the ARPA boundary area as it relates to terrestrial features of the Aleutian Islands, extending westward beyond the Alaska Peninsula from Unimak Island to Attu Island near the edge of the International Date Line. The map sheet conveys key components of Arctic geospatial information in the Aleutians otherwise absent from map sheets $1-4$, including more detailed city/village locations and relative population sizes; land-cover classification; tree-line extent (shown as the northern edge of green "Forest and woodland" areas) juxtaposed with the ARPA boundary; conservation areas (National Parks and Preserves, and National Wildlife Refuges); delineation of monitored active volcano locations; and updated geospatial information. The series of insets allows for closeup sequential review of more distant Aleutian Islands.

The map sheet shows an Alaska Polar Stereographic projection at an approximate scale of $1 \mathrm{in}$. to $59 \mathrm{mi}$ in the main frame, and $1 \mathrm{in}$. to $16 \mathrm{mi}$ in the inset frames. The map spans approximately from long $165^{\circ} \mathrm{E}$ (crossing the International Date Line) to long $136^{\circ} \mathrm{W}$., and from lat 41 to $56^{\circ} \mathrm{N}$. Relevant sections of additional data layers were selected using the attribute query tool and trace tool in Esri ArcGIS Pro, available at https:// services.arcgis.com/P3ePLMYs2RVChkJx/arcgis/rest/services/ World_GeoReference_Lines/FeatureServer. The original source file and available metadata record for the ARPA boundary shapefile shown in this map sheet can also be accessed through the U.S. Arctic Research Commission website at https://www. arctic.gov/maps/.

The population of Alaska cities and villages is derived from the 2010 U.S. Census at https://live.laborstats.alaska.gov/landing/ pop-cen.html.

Map sheet 5 shows shaded relief from recently acquired three-dimensional elevation data for land surfaces in Alaska through the AMI, as previously described in map sheet 1 . The data are free to the public for any use and can be accessed at https://geoportal.dggs.dnr.alaska.gov/portal/home/item.html?id=d 7bb272d4dcb4cfd9577f5e8e50c4ca8.

This map sheet shows the locations of monitored active volcanoes along the Aleutian arc. Alaska contains over 130 volcanoes and volcanic fields that have been active within the last 2 million years and more than 50 volcanoes and volcanic fields that have been active within historical time (since about 1760 in Alaska). These volcanoes are catalogued on the Alaska Volcano Observatory website at http://www.avo.alaska.edu/volcanoes/ and recent activity data are available at https://www.avo.alaska.edu/ activity/. 
Map sheet 5 shows vegetation land cover derived from the GAP/LANDFIRE National Terrestrial Ecosystems database, based on the NatureServe Ecological Systems Classification. These data facilitate the planning and management for biological diversity on a regional and national scale and can be accessed at https://www.usgs.gov/corescience-systems/science-analytics-and-synthesis/gap/science/ land-cover-data-overview.

This map sheet shows boundary lines of various conservation areas managed by bureaus of the Department of the Interior: the National Park Service, the Fish and Wildlife Service, and the Bureau of Land Management. The Protected Areas Database of the United States (PAD-US) is administered by the USGS and constitutes the Nation's official inventory of public open space and private protected areas (https://www.usgs. gov/core-science-systems/science-analytics-and-synthesis/gap/ science/protected-areas). The PAD-US 2.1 data can be accessed at https://maps.usgs.gov/padus/.

\section{References Cited}

Arctic Council, 2021, Arctic Council-The leading intergovernmental forum promoting cooperation in the Arctic: Arctic Council website, accessed November 2021, at https://arctic-council.org/.

Arctic Monitoring and Assessment Programme, 2021, Arctic climate change update 2021 - Key trends and impacts - Summary for policy-makers: Oslo, Norway, Arctic Monitoring and Assessment Programme (AMAP), 15 p.

Congressional Research Service, 2021, Changes in the ArcticBackground and issues for Congress: Congressional Research Service Report Number R41153, https://crsreports.congress. gov.

Esri, 2021a, ArcGIS living atlas, indications of the planet-Arctic sea ice (about this app): Esri ArcGIS web page, Sea Ice Aware app viewer, accessed November 2021, at https://livingatlas.arcgis.com/sea-ice/.

Esri, 2021b, ArcGIS living atlas, indications of the planetUSA territorial sea boundary: Esri ArcGIS web page, USA Territorial Sea Boundary, accessed November 2021, at https:/www.arcgis.com/home/item.html?id=f097586198b941 49965206a8f2471dbf.
Gibbs, A.E., and Richmond, B.M., 2017, National assessment of shoreline change-Summary statistics for updated vector shorelines and associated shoreline change data for the north coast of Alaska, U.S.-Canadian border to Icy Cape: U.S. Geological Survey Open-File Report 2017-1107, 21 p., https://doi.org/10.3133/ofr20171107.

Overland, J., Dunlea, E., Box, J.E., Corell, R., Forsius, M., Kattsov, V., Skovgård-Olsen, M., Pawlak, J., Reiersen, L., and Wang, M., 2019, The urgency of Arctic change: Polar Science, v. 21, p. 6-13, https://doi.org/10.1016/j. polar.2018.11.008.

Rekacewicz, P., 2005, Definitions of the Arctic: United Nations Environmental Programme, collection, Vital Arctic Graphics, accessed March 2, 2021, at www.grida.no/resources/7010.

Richter-Menge, J., Druckenmiller, M.L., and Jeffries, M., eds., 2019, Arctic report card 2019: National Oceanic and Atmospheric Administration, 99 p., accessed March 2, 2021, at https://arctic.noaa.gov/Portals/7/ArcticReportCard/Documents/ArcticReportCard_full_report2019.pdf.

Taylor, P.C., Maslowski, W., Perlwitz, J., and Wuebbles, D.J., 2017, Arctic changes and their effects on Alaska and the rest of the United States, chap. 11 of Wuebbles, D.J., Fahey, D.W., Hibbard, K.A., Dokken, D.J., Stewart, B.C., and Maycock, T.K., eds., Climate science special report-Fourth national climate assessment_-Volume I: Washington, D.C., U.S. Global Change Research Program, p. 303-332 accessed March 2, 2021, at https://doi.org/10.7930/J00863GK.

Thoman, R.L., Richter-Menge, J., and Druckenmiller, M.L., eds., 2020, NOAA Arctic report card 2020 executive summary: National Oceanic and Atmospheric Administration, https://doi.org/10.25923/mn5p-t549.

U.S. Geological Survey, 2016, GAP/LANDFIRE National Terrestrial Ecosystems 2011: U.S. Geological Survey data release, https://doi.org/10.5066/F7ZS2TM0.

U.S. Geological Survey, 2021, USGS EROS archive-RadarIFSAR orthorectified radar Image (ORI) Alaska: U.S. Geological Survey Earth Resources Observation and Science (EROS) Center web page, accessed November 2021, at https://www.usgs.gov/centers/eros/science/usgs-eros-archiveradar-ifsar-orthorectified-radar-image-ori-alaska.

U.S. Department of State, 2021, U.S. Extended Continental Shelf project-What is the U.S. ECS project?: U.S. Department of State web page, accessed November 2021, https://www.state.gov/about-the-u-s-extended-continentalshelf-project. 